\title{
Effects of heating the testes and epididymides of rams by scrotal insulation on fertility and embryonic mortality in ewes inseminated with frozen semen
}

\author{
R. Mieusset*, P. Quintana Casares, L. G. Sanchez Partida, S. F. Sowerbutts, \\ J. L. Zupp and B. P. Setchell
}

Department of Animai Sciences, Waite Agricultural Research Institute, University of Adelaide, Glen Osmond, SA 5064, Australia

\begin{abstract}
Summary. Fertilization rate and embryonic mortality were assessed in 636 ewes inseminated in each uterine horn with $50 \times 10^{6}$ frozen spermatozoa from four control rams and from four rams submitted to a moderate $\left(1 \cdot 4-2 \cdot 2^{\circ} \mathrm{C}\right)$, but repeated, intermittent ( $16 \mathrm{~h} /$ day for 21 consecutive days) increase in their subcutaneous scrotal temperature by means of scrotal insulation. Pregnancy was assessed twice in each ewe from concentration of progesterone in blood plasma at 17 days and by ultrasound at 65 days after insemination. No differences were observed in the pregnancy rate at 17 days between ewes inseminated with semen collected from control rams $(56 \cdot 0,65 \cdot 2,66 \cdot 7$ and $60 \cdot 3 \%)$ and from heated rams $(60 \cdot 6,71 \cdot 8,63 \cdot 6$ and $48 \cdot 2 \%)$ before or after 4,15 and 21 days of heating, respectively. In contrast, the rate of embryonic mortality between 17 and 65 days after insemination was significantly higher at days 4,15 and 21 in the heated rams (78.7, 78.6 and $93 \%$ ) than in the control rams $(55,59$ and $65.7 \%)$. These results indicate that an intermittent slight, but repeated, increase in the subcutaneous scrotal temperature could induce a significant increase in the embryonic mortality rate. As these changes were apparent on day 4 of heating, an effect must have occurred on sperm stored in the epididymis.
\end{abstract}

Keywords: embryonic mortality; fertility; scrotum; sheep; temperature

\section{Introduction}

It is well known that spermatogenesis in mammals with scrotal testes is susceptible to damage if the testicular temperature is higher than normal (see Waites \& Setchell, 1990). It has also been reported that the fertility of animals subjected to an increase in whole-body or testicular temperature is depressed or even suppressed (Waites, 1968). Reduced fertility in females mated with heat-stressed males can result from (i) failure in fertilization (ram: Dutt \& Simpson, 1957; Fowler \& Dun, 1966; Howarth, 1969; Rathore, 1970; Braden \& Mattner, 1970; boar: Wettemann \& Bazer, 1985), (ii) a normal fertilization, but an increase in embryonic death (mice: Bellvé, 1972; rabbit: Howarth et al., 1965; Burfening \& Ulberg, 1968), or (iii) a failure in fertilization or an increase in embryonic death (ram: Rathore, 1970; boar: Wettemann \& Bazer, 1985; mice: Burfening et al., 1970; rat: Setchell et al., 1988). In cryptorchid rabbits, sperm lose the ability to fertilize within 2 days, but there is no effect on implantation (Cummins \& Gover, 1970). However, it is difficult to assess the relevance of many of these reports since, in most of these studies with general heating, body temperature was raised by about $1^{\circ} \mathrm{C}$ because of the high ambient temperature, but testis

*Present address: Centre de Stérilité Masculine, Hôpital La Grave, 31052 Toulouse Cedex, France. 
temperature was not measured; in the studies using local heating, testicular temperature was raised to nonphysiological levels $\left(40-43^{\circ} \mathrm{C}\right)$.

In fertile men, an induced increase of $1-2^{\circ} \mathrm{C}$ in testicular temperature resulted in a marked depression in spermatogenesis (Mieusset et al., 1987a). In infertile men, at least one-third were reported to have an increase in scrotal temperature of $\approx 0.5-1.5^{\circ} \mathrm{C}$ (Mieusset et al., 1987b; Zorgniotti \& Sealfon, 1988) and this increase was associated with significant alterations in the exocrine and endocrine functions of the testis (Mieusset et al., 1989).

The present study assessed the fertilization rate and embryonic mortality in normal female sheep inseminated with semen from rams submitted to moderate, but sustained, increases in scrotal temperature.

\section{Materials and Methods}

\section{Animals}

Eight mature Australian Merino rams 3-5 years old and weighing $65-75 \mathrm{~kg}$ were kept in individual pens in a room with controlled temperature and light, at $19-23^{\circ} \mathrm{C}$ under a regimen of $16 \mathrm{~h} \mathrm{light}$ and $8 \mathrm{~h}$ dark. Four animals were used as control; they were fed ad libitum with standard rations twice a day with free access to water.

\section{Treatment}

The scrotum was heated for $16 \mathrm{~h} /$ day, beginning $4 \mathrm{~h}$ before the end of the light period, for 21 successive days by means of an insulating bag made up of one layer of aluminium foil inserted between two layers of cotton cloth and, on the outside, one layer of waterproof cotton cloth (Malmgren \& Larsson, 1989). The bag surrounded the scrotum without inducing any compression and was maintained in this position by four tapes tied over the back of the ram.

Preliminary assessment of the increase in temperature was performed on five other similar rams. Under a short anaesthesia induced with $0.4 \mathrm{ml}$ of xylazine i.v. (Rompun; Bayer, Australia), a probe for recording temperature was placed into the space between the tunica vaginalis and the scrotal skin through a small incision in the skin $\approx 10 \mathrm{~cm}$ above the testis. The probe was maintained in position by suturing the scrotal skin, and temperatures were recorded every $5 \mathrm{~min}$ for $2-6 \mathrm{~h}$ from the first to the fifth day after surgery, with the scrotum insulated as described. In all cases the mean subcutaneous scrotal temperature was $1.4-2 \cdot 2^{\circ} \mathrm{C}$ higher than control values, with a mean $( \pm \mathrm{SD})$ increase of $1 \cdot 7 \pm 0 \cdot 3^{\circ} \mathrm{C}$.

\section{Semen analyses and freezing}

Semen was collected twice a week by artificial vagina and analysed manually for number of sperm (Improved Neubauer cell; Weber, UK) and vitality (eosin-nigrosin staining; 200 spermatozoa counted). Motility characteristics were assessed by a computerized image analyser (Hamilton Thorn Motility Analyser; Daintree Ind., Australia). On day 49 before treatment and days 4,15 and 21 during treatment, semen was diluted five-fold with Tris-glucose egg yolk-glycerol at $32^{\circ} \mathrm{C}$ with $\mathrm{pH}$ controlled at 7 with citric acid and pellet-frozen on dry-ice (Evans \& Maxwell, 1987). The pellets were kept in liquid nitrogen until thawed in dry test tubes, which were shaken in a water bath at $37^{\circ} \mathrm{C}$, and the semen was used for insemination within $10 \mathrm{~min}$. At least one pellet from each batch was analysed after thawing.

\section{Insemination}

Six-hundred and forty mature Merino ewes were randomly distributed into eight groups of 80 ewes and their oestrous cycles synchronized with progestagen sponges (Repromap, Upjohn, Australia), which were left in situ for 12 days, and $400 \mathrm{iu}$ of pregnant mares' serum gonadotrophin (Folligon, Intervet, Australia) injected i.m. at the time of sponge removal. Every day, 80 ewes were inseminated $50 \mathrm{~h}$ after sponge removal: 40 with semen from heated rams and 40 with semen from control rams, the date of collection being selected at random. Insemination was performed through a laparoscope by deposition of $50 \times 10^{6}$ spermatozoa in each uterine horn. The same number of spermatozoa was used for treated and control rams. Because on three occasions (twice in the control and once in the heated group) no semen could be collected from one ram, 324 ewes were inseminated with semen from heated rams and 312 with semen from control rams.

\section{Pregnancy diagnosis}

Two successive determinations of pregnancy were performed on each ewe 17 and 65 days after insemination. The first diagnosis was made by determining the concentration of progesterone in plasma at day 17 (assessed in duplicate by radioimmunoassay) and a pregnancy was recorded when the progesterone value was at least $2 \mathrm{ng} / \mathrm{ml}$ (Robertson, 
1977). The second determination was made by ultrasonic examination at 65 days (Lindahl, 1976). A female pregnant on day 17 and not on day 65 after insemination was considered to have lost its embryo.

\section{Progesterone assay}

An extraction single-antibody radioimmunoassay was used to measure concentrations of progesterone in plasma (D'Occhio et al., 1988). Nonradioactive progesterone was purchased from Sigma Chemicals (USA) and $(1,2,6,7-$ tritiated) progesterone was obtained from the Radiochemical Centre (Amersham, Bucks, UK). Progesterone was extracted into heptane by vigorous vortexing and, after freezing of the aqueous phase, the heptane was transferred to assay tubes and evaporated by warming to $43^{\circ} \mathrm{C}$ in a water bath and blowing with air. Tritiated progesterone and antiserum were then added and the mixture was incubated overnight at $4{ }^{\circ} \mathrm{C}$. Dextran-coated charcoal was used to separate bound and free steroid, and radioactivity in the bound fraction was determined using a liquid scintillation spectrometer. The intra- and interassay coefficients of variation were 8.4 and $8.7 \%$, respectively; the limit of the sensitivity was $0 \cdot 19 \mathrm{ng} / \mathrm{ml}$.

\section{Statistical analysis}

The numbers of pregnant females were compared by $\chi^{2}$ test. Between-group comparisons of the semen variables were performed by unpaired Student's $t$-test, and within-ram comparisons at different times by paired Student's $t$-test.

\section{Results}

\section{Semen characteristics}

Before the scrotal insulation, no difference was observed between the control and heated rams in the total number of spermatozoa, the number of dead spermatozoa or the percentages of motile and rapid spermatozoa (Table 1). On day 4 of heating, the only difference between the two groups was a lower percentage of rapid spermatozoa $(P<0.05)$ in the heated rams. On day 15 of heating, the mean number of dead spermatozoa in the heated rams was significantly higher than in the control rams on the same day $(P<0.01)$ and than in the heated rams before treatment $(P<0.05)$. On day 21 of heating, there were more dead spermatozoa $(P<0.01)$, and the percentages of motile $(P<0.01)$ and of rapid $(P<0.01)$ spermatozoa were lower in the heated than in the control rams, but the total number of spermatozoa did not differ between the two groups. However, in the heated group the total number of spermatozoa and the percentages of motile and of rapid spermatozoa were lower at 21 days of heating $(P<0.05)$ than in the same rams before treatment.

Table 1. Fresh semen characteristics (mean \pm SEM) in control and scrotally insulated rams before and during the heating period

\begin{tabular}{|c|c|c|c|c|c|c|c|c|}
\hline \multirow[b]{2}{*}{ Days } & \multicolumn{2}{|c|}{$\mathrm{TSC}^{\mathrm{a}}$} & \multicolumn{2}{|c|}{ Dead $^{b}$} & \multicolumn{2}{|c|}{ Motility $(\%)^{\mathfrak{c}}$} & \multicolumn{2}{|c|}{ Rapid $(\%)^{d}$} \\
\hline & C & H & $\mathrm{C}$ & $\mathrm{H}$ & $\mathrm{C}$ & $\mathrm{H}$ & $\mathrm{C}$ & $\mathrm{H}$ \\
\hline-49 & $\begin{array}{c}3 \cdot 1 \\
(0 \cdot 7)\end{array}$ & $\begin{array}{c}4.5 \\
(0 \cdot 3)\end{array}$ & $\begin{array}{l}12 \cdot 4 \\
(2 \cdot 7)\end{array}$ & $\begin{array}{l}17 \cdot 3 \\
(3 \cdot 2)\end{array}$ & $\begin{array}{c}63 \cdot 2 \\
(10 \cdot 1)\end{array}$ & $\begin{array}{c}79 \cdot 1 \\
(10 \cdot 5)\end{array}$ & $\begin{array}{l}28 \cdot 9 \\
(6 \cdot 0)\end{array}$ & $\begin{array}{l}39 \cdot 1 \\
(8 \cdot 5)\end{array}$ \\
\hline 4 & $\begin{array}{c}2 \cdot 3 \\
(0.4)\end{array}$ & $\begin{array}{c}2 \cdot 7 \\
(0 \cdot 4)\end{array}$ & $\begin{array}{l}16.9 \\
(8.8)\end{array}$ & $\begin{array}{c}28.5 \\
(10.3)\end{array}$ & $\begin{array}{c}56 \cdot 8 \\
(10.6)\end{array}$ & $\begin{array}{c}47.7 \\
(11.5)\end{array}$ & $\begin{array}{l}24 \cdot 0 \\
(3 \cdot 9)\end{array}$ & $\begin{array}{l}12.54 \\
(6.1)\end{array}$ \\
\hline 15 & $\begin{array}{c}2.5 \\
(0.2)\end{array}$ & $\begin{array}{c}2.9 \\
(0.8)\end{array}$ & $\begin{array}{l}12.7 \\
(3.0)\end{array}$ & $\begin{array}{l}38.3^{*}+ \\
(1.8)\end{array}$ & $\begin{array}{l}77 \cdot 0 \\
(2 \cdot 7)\end{array}$ & $\begin{array}{l}55 \cdot 2 \\
(8.2)\end{array}$ & $\begin{array}{l}36.9 \\
(2.7)\end{array}$ & $\begin{array}{l}18 \cdot 8 \\
(7 \cdot 2)\end{array}$ \\
\hline 21 & $\begin{array}{c}3.6 \\
(0.7)\end{array}$ & $\begin{array}{r}2 \cdot 6 \dagger \\
(0.5)\end{array}$ & $\begin{array}{c}8.5 \\
(1.6)\end{array}$ & $\begin{array}{l}56 \cdot 9^{*} \\
(7 \cdot 2)\end{array}$ & $\begin{array}{l}74 \cdot 6 \\
(0.9)\end{array}$ & $\begin{array}{l}17^{*++}++ \\
(6 \cdot 4)\end{array}$ & $\begin{array}{l}38.7 \\
(6.9)\end{array}$ & $\begin{array}{l}5 \cdot 5^{*} \dagger \\
(2 \cdot 0)\end{array}$ \\
\hline
\end{tabular}

C: control; $\mathrm{H}$ : heated.

Numbers in parenthesis are SEMs.

${ }^{a}$ Total sperm count $\left(10^{9}\right.$ spermatozoa per ejaculate): sperm count $\times$ volume.

${ }^{\mathrm{b}}$ Percentage of dead spermatozoa assessed on 200 cells.

'The proportion of total cells for which path velocity was $>10 \mu \mathrm{m} \mathrm{s}^{-1}$.

${ }^{\mathrm{d}}$ The proportion of all cells moving with path velocity $>95 \mu \mathrm{m} \mathrm{s}^{-1}$.

${ }^{*} P<0.01$ compared with control group value on the same day; $\dagger P<0.05$ and $\ddagger P<0.01$ compared with values at day -49 and day 15 respectively in the heated group. 


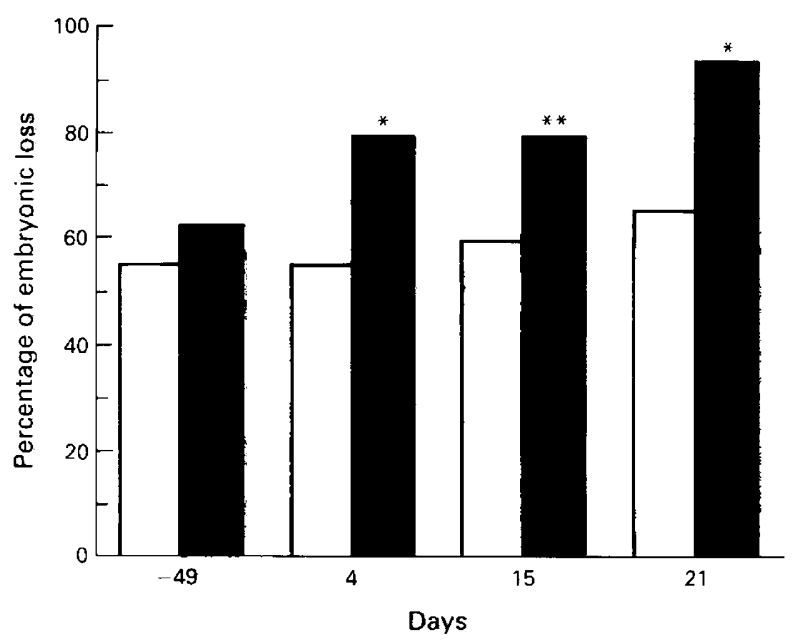

Fig. 1. Percentage of embryonic loss between day 17 and day 65 after insemination with frozenthawed spermatozoa from control (open bars) and scrotally insulated (solid bars) rams. Values significantly different from control group on the same day: ${ }^{*}=P<0.01$ and ${ }^{* *}=P<0.05$.

1970), boars (Wettemann \& Bazer, 1985) and rats (Setchell et al., 1988) and of cryptorchidism in rabbits (Cummins \& Glover, 1970). Besides a difference in the heating procedure, with testicular temperature raised to $40-43^{\circ} \mathrm{C}$ (Braden \& Mattner, 1970; Setchell et al., 1988), or with general modifications induced through a whole-body increase in temperature (Dutt \& Simpson, 1957; Fowler \& Dun, 1966; Rathore, 1968, 1970; Howarth, 1969; Braden \& Mattner, 1970; Wettemann \& Bazer, 1985), in some of these studies problems of methodology could have been involved, such as few control males (Rathore, 1968, 1970; Braden \& Mattner, 1970) or of mated females (Fowler \& Dun, 1966). But more important is that the reduction in the fertilization rate reported in some of these studies was obtained from animals in which semen characteristics were drastically altered by a long exposure to heat, ranging from 45 to 80 days (Dutt \& Simpson, 1957; Wettemann \& Bazer, 1985).

The high embryonic mortality rate $(55-68 \%)$ in the ewes inseminated with frozen-thawed semen from control rams confirmed the previous reports of the interference by the surgical technique used in the intra-uterine insemination of ewes (Maxwell et al., 1984). Nevertheless, in the present study, in which embryonic mortality calculated from the difference in the number of ewes pregnant at 17 and 65 days after insemination was underestimated, as a ewe can be pregnant with two embryos at 17 days and with only one fetus at 65 days (Nottle et al., 1988), embryonic loss was significantly increased in ewes inseminated with semen from the heated rams as early as day 4 of treatment, while there was no modification in the fertilization rate. Besides experimental conditions, these discrepancies from previous studies could be due to species differences in response to temperature increase, as in rabbits in which artificial cryptorchidism results in failure of fertilization within 2 days, but has no effect on the implantation of embryos (Cummins \& Glover, 1970), or to a difference in sensitivity to heat of different breeds of the same species, as in rams (Fowler \& Dun, 1966). However, the lack of modification in the fertilization rate associated with an increase in the embryonic death observed in the present study is in agreement with the results reported in mice (Burfening et al., 1970; Bellvé, 1972) and rats (Setchell et al., 1988) when the females were mated with males immediately after heat treatment, and in rabbits when spermatozoa were heated before insemination (Howarth et al., 1965; Burfening \& Ulberg, 1968). As implantation of the embryo takes place in ewes 15-24 days after fertilization (Robertson, 1977) and as the first diagnosis of pregnancy was performed on day 17 after insemination, it cannot be deduced from the present study whether the embryonic loss occurred before or after implantation. 
The greater loss of embryos in the heated group could be seen as a result of the use of frozen semen, as already suggested in boars (Wettemann \& Bazer, 1985), i.e. spermatozoa from the rams with insulated scrotum might be more sensitive to freezing than sperm from control animals, because they have 'suffered' from the effects of increased temperature. It will be important to see whether embryonic mortality is greater in ewes inseminated with fresh semen from insulated rams, but, if increased susceptibility to freezing is involved, one would expect a decrease in fertilization rate, which does not occur until day 21 of scrotal insulation. Furthermore, as the effect occurred as early as day 4 of insulation, this would indicate that spermatozoa already in the epididymis can also be made more susceptible to the effects of freezing.

The epididymis is thought to be resistant to heat, from the lack of abnormal spermatozoa or of modification in the motility of spermatozoa in the ejaculates of rams or boars until $\approx 14$ days after heating (Glover, 1955; Moule \& Waites, 1963; Waites \& Setchell, 1964; Wettemann \& Bazer, 1985). Such resistance was also confirmed in rams by the lack of change in fertilization rate within the first week after heating in some studies using a few males or females (Howarth, 1969; Braden \& Mattner, 1970). However, in rats, mice and bulls, the lower temperature of the cauda epididymidis has been shown to facilitate the storage of sperm by enhancing oxygen availability (Djakiew \& Cardullo, 1986). As in rams, the passage of spermatozoa through the epididymis requires $\approx 11-14$ days (Ortavant, 1954), the increase in the embryonic death at day 4 of heating in the present experiment indicates an effect of heat on the epididymal spermatozoa. Such an effect on embryonic survival was already present, although the authors do not comment on this point, when mice were mated during the first week after heating (Burfening et al., 1970; Bellvé, 1972).

Different mechanisms can be evoked for the reduced capacity of the spermatozoa to induce a viable embryo: developmental retardation of the embryo before implantation (Bellvé, 1972); reduced capacity to induce implantation sites, either as a direct effect of heat or as a result of the slower division of the embryo through desynchronization with the uterine environment, and such a desynchronization could also be involved in post-implantation embryonic death. Epididymal maturation of the spermatozoa could be affected by raised temperatures and embryo mortality is known to be increased in fertilizations with immature, epididymal spermatozoa (Fournier-Delpech et al., 1981); however, this does not explain the early increase in embryonic loss observed on day 4 of heating. Exposure of mice to $35^{\circ} \mathrm{C}$ for $2-5$ days caused dissociation of the $\mathrm{X}-\mathrm{Y}$ chromosome bivalent in diakinesis-metaphase primary spermatocytes as well as formation of multinucleated giant cells in the testis (Waldbieser \& Chrisman, 1986). If, as suggested by these authors, cell aberrations resulting from these anomalies are involved in the reduced fertility of scrotal mammals subjected to high temperatures, this does not explain the early increase in embryonic loss on day 4 of scrotal insulation. Whatever the mechanism, the alterations induced in the spermatozoa by heating such as that used in the present study must manifest themselves at a later stage than fertilization, which proceeds normally.

The results of the present experiment show that increasing the subcutaneous scrotal temperature by $\approx 2^{\circ} \mathrm{C}$ for $16 \mathrm{~h} /$ day in rams induced, as soon as day 4 of treatment, an increase in embryonic loss without any modification in the fertilization rate, at least until 21 days of heating, when the quality and, to a lesser extent, the quantity of the spermatozoa are affected. Thus, the earliest effect of heat seems to be on epididymal spermatozoa. From these results and those reported in the literature, we suggest that the sequence of the heat effects on spermatogenesis could be (i) a reduction in the capacity of the spermatozoa to produce a viable embryo, (ii) a decrease in the number of living and motile spermatozoa, (iii) a decrease in the capacity of the spermatozoa to fertilize the ovum and (iv) a decrease in the number of spermatozoa produced. More detailed analyses, such as maturity of the nuclear proteins or chromatin status, are required to establish a relation between the spermatozoa and this sequence.

Financial support for this project was provided from Cecos Midi-Pyrénées and Inserm U168 for R. Mieusset and by a small grant from the Australian Research Council. 


\section{References}

Bellvé, A.R. (1972) Viability and survival of mouse embryos following parental exposure to high temperature. J. Reprod. Fert. 30, 71-81.

Braden, A.W.H. \& Mattner, P.E. (1970) The effects of scrotal heating in the ram on semen characteristics, fecundity and embryonic mortality. Aust. J. agric. Res. 12, 509-518.

Burfening, P.J. \& Ulberg, L.C. (1968) Embryonic survival subsequent to culture of rabbit spermatozoa at $38^{\circ}$ and $40^{\circ}$ C. J. Reprod. Fert. 15, 87 92.

Burfening, P.J., Elliott, D.S., Eisen, E.J. \& Ulberg, L.C. (1970) Survival of embryos resulting from spermatozoa produced by mice exposed to elevated ambient temperature. J. Anim. Sci. 30, 578-582.

Cummins, J.M. \& Glover, T.D. (1970) Artificial cryptorchidism and fertility in the rabbit. J. Reprod. Fert. 23, 423-434.

Djackiew, D. \& Cardullo, R. (1986) Lower temperature of the cauda epididymidis facilitates the storage of sperm by enhancing oxygen availability. Gam. Res. 15, 237.245.

D'Occhio, M.J., Gifford, D.R., Hoskinson, R. Weatherly, T. \& Setchell, B.P. (1988) Gondotrophin secretion and ovarian responses in prepubertal heifers actively immunized against androstenedions and oestradiol17ß. J. Reprod. Fert. 83, 159-168.

Dutt, R.H. \& Simpson, E.C. (1957) Environmental temperature and fertility of Southdown rams early in the breeding season. J. Anim. Sci. 16, 136-143.

Evans, G. \& Maxwell, W.M.C. (1987) Use of frozen semen in sheep. In Salamon's Artificial Insemination of Sheep and Goats, pp. 122-124. Eds G. Evans \& W. M. C. Maxwell. Butterworths, Sydney.

Fournier-Delpech, S., Colas, G. \& Courot, M. (1981) Observations sur les premiers clivages des oeufs intratubaires de brebis après fécondation avec des spermatozoïdes épididymaires ou éjaculés. C.r.h. Séanc. Acad. Sci. Paris D 192, 515-517.

Fowler, D.G. \& Dun, R.B. (1966) Skin folds and merino breeding. 4 . The susceptibility of rams selected for a high degree of skin wrinkle to heat induced infertility. Aust. J. exp. Agric. Anim. Husband. 6, 121-127.

Glover, T.D. (1955) Some effects of scrotal insulation on the semen of rams. Proc. Soc. Study Fert. 7, 66-75.

Howarth, B. (1969) Fertility in the ram following exposure to elevated ambient temperature and humidity. J. Reprod. Fert. 19, 179-183.

Howarth, B., Alliston, C.W. \& Ulberg, L.C. (1965) Importance of uterine environment on rabbit sperm prior to fertilization. J. Anim. Sci. 24, 1027-1032.

Lindahl, I.L. (1976) Pregnancy diagnosis in ewes by ultrasonic scanning. J. Anim. Sci. 43, $1135-1142$.

Malmgrem, L. \& Larsson, K. (1989) Experimentally induced testicular alterations in boars: histological and uitrastructural findings. J. Vet. Med. A 36, 3-14.

Maxwell, W.M.C., Butler, G.L. \& Wilson, H.R. (1984) Intra-uterine insemination of ewes with frozen semen. J. agric. Sci., Cambridge 102, 233-235.

Mieusset, R., Bujan, L., Mansat, A., Pontonnier, F. \& Grandjean, H. (1987a) Hyperthermia and human spermatogenesis: enhancement of the inhibitory effect obtained by 'artificial cryptorchidism'. Int. J. Androl. 10, $571-580$.

Mieusset, R., Bujan, L., Mondinat, C., Mansat, A., Pontonnier, F. \& Grandjean, H. (1987b) Association of scrotal hyperthermia with impaired spermatogenesis in infertile men. Fert. Steril. 48, 1006-1011.

Mieusset, R., Bujan, L., Plantavid, M. \& Grandjean, H. (1989) Increased levels of serum FSH and LH associated with intrinsic testicular hyperthermia in oligospermic infertile men. J. Clin. Endocr. Metab. 68, 419-425.

Moule, G.R. \& Waites, G.M.H. (1963) Seminal degeneration in the ram and its relation to the temperature of the scrotum. J. Reprod. Fert. 5, 433-436.

Nottle, M.B., Hind, P.I., Seamark, R.F. \& Setchell, B.P. (1988) Increases in ovulation rate in protein digested post-ruminally. J. Reprod. Fert. 84, 563-566.

Ortavant, R. (1954) Détermination de la vitesse de transfert des spermatozoïdes dans l'épididyme du bélier à l'aide du ${ }^{32}$ P. C.r. Soc. Biol. Paris 147, 1152-1155.

Rathore, A.K. (1968) Effects of high temperature on sperm morphology and subsequent fertility in Merino sheep. Proc. Aust. Soc. Anim. Prod. 7, 270-274.

Rathore, A.K. (1970) Fertility of rams heated for 1, 2, 3 and 4 days, mated to superovulated ewes. Aust. J. agric. Res. 21, 355-358.

Robertson, H.A. (1977) Reproduction in the ewe and the goat. In Reproduction in Domestic Animals, pp. 475 498. Eds H. H. Cole \& P. T. Cupps. Academic Press, New York.

Setchell, B.P., D'Occhio, M.J., Hall, M.J., Laurie, M.S., Tucker, M.J. \& Zupp, J.L. (1988) Is embryonic mortality increased in normal females mated to subfertile males? J. Reprod. Fert. 82, 567-574.

Waites, G.M.H. (1968) Temperature and fertility in mammals. In Proceedings of the 6 th International Congress of Reproduction and Artificial Insemination, Vol. 1, pp. 235-252, Raven Press, New York.

Waites, G.M.H. \& Setchell, B.P. (1964) Effect of local heating on blood flow and metabolism in the testis of conscious ram. J. Reprod. Fert. 8, 339-349.

Waites, G.M.H. \& Setchell, B.P. (1990) Physiology of the mammalian testis. In Marshall's Physiology of Reproduction, Vol. 2, pp. 1-105. Eds G. E. Lamming. Churchill Livingstone, London.

Waldbiesser, G.C. \& Chrisman, C.L. (1986) X-Y chromosome univalency in the testes of hyperthermic mice: I. Concomitant formation of multinucleated giant cells. Gam. Res. 15, 153-160.

Wettemann, R.P. \& Bazer, F.W. (1985) Influence of environmental temperature on prolificacy of pigs. $J$. Reprod. Fert. Suppl. 33, 199-208.

Zorgniotti, A.W. \& Sealfon, A.I. (I988) Measurement of intrascrotal temperature in normal and subfertile men. J. Reprod. Fert. 82, 563-567.

Received 10 December 1990 